\title{
Virulence, antimicrobial and heavy metal tolerance, and genetic diversity of Vibrio cholerae recovered from commonly consumed freshwater fish
}

\author{
Mengjie $\mathrm{Xu}^{1} \cdot$ Jinrong $\mathrm{Wu}^{2} \cdot$ Lanming $\mathrm{Chen}{ }^{1}$
}

Received: 7 January 2019 /Revised: 7 April 2019 / Accepted: 25 April 2019 / Published online: 19 July 2019

(C) The Author(s) 2019

\begin{abstract}
Vibrio cholerae is a leading waterborne pathogen worldwide. Continuous monitoring of $V$. cholerae contamination in aquatic products and identification of risk factors are crucial for assuring food safety. In this study, we determined the virulence, antimicrobial susceptibility, heavy metal tolerance, and genetic diversity of $400 \mathrm{~V}$. cholerae isolates recovered from commonly consumed freshwater fish (Aristichthys nobilis, Carassius auratus, Ctenopharyngodon idellus, and Parabramis pekinensis) collected in July and August of 2017 in Shanghai, China. V. cholerae has not been previously detected in the half of these fish species. The results revealed an extremely low occurrence of pathogenic $V$. cholerae carrying the major virulence genes $c t x A B$ $(0.0 \%), t c p A(0.0 \%)$, ace $(0.0 \%)$, and $z o t(0.0 \%)$. However, high incidence of virulence-associated genes was observed, including the RTX toxin gene cluster $(r t x A-D)(83.0-97.0 \%), h l y A(87.8 \%)$, hapA (95.0\%), and th (76.0\%). Meanwhile, high percentages of resistance to antimicrobial agents streptomycin (65.3\%), ampicillin (44.5\%), and rifampicin (24.0\%) were observed. Approximately $30.5 \%$ of the isolates displayed multidrug resistant (MDR) phenotypes with 42 resistance profiles, which were significantly different among the four fish species (MARI, $P=0.001$ ). Additionally, tolerance of isolates to heavy metals $\mathrm{Hg}^{2+}$ (49.3\%), $\mathrm{Zn}^{2+}(30.3 \%)$, and $\mathrm{Pb}^{2+}(12.0 \%)$ was observed. The enterobacterial repetitive intergenic consensus-polymerase chain reaction (ERIC-PCR)-based fingerprinting of the $400 \mathrm{~V}$. cholerae isolates revealed 328 ERIC-genotypes, which demonstrated a large degree of genomic variation among the isolates. Overall, the results of this study support the need for food safety risk assessment of aquatic products.
\end{abstract}

Keywords Vibrio cholerae $\cdot$ Virulence $\cdot$ Antimicrobial susceptibility $\cdot$ Heavy metal tolerance $\cdot$ Genotyping $\cdot$ Freshwater fish

Mengjie Xu and Jinrong Wu contributed equally to this work.

Responsible editor: Diane Purchase

Electronic supplementary material The online version of this article (https://doi.org/10.1007/s11356-019-05287-8) contains supplementary material, which is available to authorized users.

Lanming Chen

lmchen@shou.edu.cn

1 Key Laboratory of Quality and Safety Risk Assessment for Aquatic Products on Storage and Preservation (Shanghai), China Ministry of Agriculture, College of Food Science and Technology, Shanghai Ocean University, 999 Hu Cheng Huan Road, Shanghai 201306, People's Republic of China

2 College of Life Science and Technology, Xinjiang University, Xinjiang 830000, People's Republic of China

\section{Introduction}

Vibrio cholerae can cause cholera, a severe diarrheal disease that can be quickly fatal if untreated and is typically transmitted via contaminated water and person-to-person contact (Baker-Austin et al. 2018). It was estimated that $V$. cholera caused roughly 2.9 million cases of cholera and 95,000 deaths annually worldwide between 2008 and 2012 (Ali et al. 2015). The bacterium is found growing in aquatic environment or aquatic products such as crustaceans and fish (Vezzulli et al. 2010). Previous studies highlighted the link between cholera outbreaks and the consumption of raw, undercooked, or mishandled fish products contaminated by $V$. cholerae. For instance, consumption of dried fish was significantly associated with the 1997 cholera epidemic in a rural area (Ifakara) in southern Tanzania (Acosta et al. 2001). It has also been reported that the fresh fish imported from Nigeria contributed to the domestic cholera in Germany in 2001 (Schurmann et al. 
2002). Since 2002, China has become the largest producer and exporter in the world for fishery products, which accounted for $62.6 \%(69,012,500$ tons) of the global amount in 2016. Freshwater aquaculture is an important component of Chinese fishery production, and accounted for $48.4 \%$ of the total fishery output value in China (Zhang et al. 2018). C. idellus (known as grass carp) is the most important freshwater cultured fish with the largest production in China, and its total output exceeded 5,676,235 tons in 2015 (Jia et al. 2016). C. auratus (known as crucian carp) has been cultured in China for several hundred years (Jing et al. 2016), and recently played an important role in the international fish trade with a total output of 2,912,258 tons in 2015 (Jia et al. 2016). A. nobilis (known as bighead carp) and $P$. pekinensis (known as white bream) are also two of the most dominant fish species in freshwater aquaculture in China. Therefore, continuous monitoring of $V$. cholerae contamination in freshwater fish is imperative for food safety control.

Two major virulence genes that encode cholerae toxin (CT) and toxin coregulated pilus (TCP) have been identified in epidemic $V$. cholerae strains of serotypes $\mathrm{O} 1$ and $\mathrm{O} 139$. These toxin genes are carried by a lysogenic filamentous bacteriophage (CTX prophage) that can integrate into $V$. cholerae chromosomes (Waldor and Mekalanos 1996). The nonepidemic $V$. cholerae strains, referred to non-O1/O139, can cause sporadic episodes of diarrhea and gastrointestinal infection (Austin 2010; Ceccarelli et al. 2015). The genes encoding virulence-associated factors that contribute to the pathogenicity of $V$. cholerae include the zonula occludens toxin (zot) (Preeprem et al. 2014), accessory cholera enterotoxin (ace) (Briquaire et al. 2017), RTX toxin gene cluster ( $r t x A-D)$ (Lin et al. 1999), El Tor hemolysin (hlyA) (Ruenchit et al. 2017), thermolabile hemolysin ( $t$ lh) (Fiore et al. 1997), hemagglutinin protease (hapA) (Halpern et al. 2003), and two morphologically distinct types of pili, namely, mannose-sensitive hemagglutination (MSHA) pili ( $m s h a$ ) (Moorthy and Watnick 2004) and putative type IV pilus (pil) (Fullner and Mekalanos 1999).

Antimicrobial agent treatment can effectively control outbreaks and prevalence of infectious diseases caused by pathogenic microorganisms. However, the inappropriate usage of antimicrobial drugs in aquaculture contributed to the development of antimicrobial-resistant bacteria and imposed potential threat upon human health due to the dissemination of antimicrobial resistance (Woolhouse and Farrar 2014). The aquatic environment is a reservoir of $V$. cholerae and might be an important source of resistant strains (Baron et al. 2017). Numerous previous studies have been focused on the detection of $V$. cholerae from various aquatic environments. For instance, Sulca et al. reported that two $V$. cholera isolates from Lima (Peru) seawater were resistant to 12 antimicrobial drugs, including ampicillin (AMP), penicillin, amoxicillin, nitrofurantion, kanamycin (KAN), amikacin, aztreonam, ciprofloxacin, gentamicin (CN), co-trimoxazole, ceftazidime, and nalidixic acid (Sulca et al. 2018). Bhuyan et al. also reported that $107 \mathrm{~V}$. cholerae strains originated from different aquatic environment (including river water, canal water, pond water, and hand-pump water) in India showed varying degrees of resistance to AMP, co-trimoxazole, nalidixic acid, polymyxin-B, streptomycin (STR), ciprofloxacin, and tetracycline (TET) (Bhuyan et al. 2016). Antimicrobial-resistant $V$. cholerae isolated from aquacultured animals such as shrimps and shellfish have also been reported. For example, $\mathrm{He}$ et al. analyzed $42 \mathrm{~V}$. cholerae isolates recovered from shrimp collected in 2013 and 2014 in Shanghai, China, and found that $33.3 \%, 21.4 \%, 19.1 \%, 9.5 \%$, and $9.5 \%$ of the isolates were resistant to rifampicin (RIF), STR, KAN, AMP, and TET, respectively. Moreover, 25 isolates (59.5\%) had MDR phenotypes (He et al. 2015).

$V$. cholerae has been isolated from approximately 30 fish species belonging to nine different orders within the Actinopterygii class (Halpern and Izhaki 2017). The bacterium was found to reside in healthy fish intestines (Halpern and Izhaki 2017). For instance, $V$. cholerae was detected from the intestines of ten freshwater fish species collected in Israel in 2008, including Astatotilapia flaviijosephi, Barbus longiceps, Carasobarbus canis, C. idella, Cyprinus carpio, Mugil cephalus, Myripristis murdjan, Oreochromis aureus, Sarotherodon galilaeus, and Tilapia sp. and Tilapia zilli (Senderovich et al. 2010). Recently, V. cholerae was also isolated from four freshwater fish species (C. auratus, C. idella, Cyprinus carpio, and Hypophthalmichthys molitrix) collected in Chengdu, China (Li et al. 2017). Laviad-Shitrit et al. reported that $95.8 \%$ of $V$. cholerae isolates (non-O1/O139) $(n=48)$ derived from fish intestines showed high minimal inhibitory concentration (MIC) $\left(\mathrm{MIC}_{90}\right.$ of $16 \mu \mathrm{g} / \mathrm{mL}$ ) to doxycycline (Laviad-Shitrit et al. 2018).

Water contaminated with heavy metals may enhance selection for antibiotic resistance and vice versa (Baker-Austin et al. 2006; Matyar 2012). The commonly detected heavy metals in the environment include chromium $(\mathrm{Cr})$, zinc $(\mathrm{Zn})$, cadmium $(\mathrm{Cd})$, copper $(\mathrm{Cu})$, mercury $(\mathrm{Hg})$, nickel $(\mathrm{Ni})$, and lead $(\mathrm{Pb})$ (Wuana and Okieimen 2011). Nevertheless, very little information is available concerning the tolerance of $V$. cholerae to heavy metals to date. In our prior study, our data revealed that V. cholerae isolates Chn64, Chn86, Chn91, Chn92, and Chn108 derived from the surface water of Yangtze River Estuary in Shanghai, China, showed high levels of tolerance to $\mathrm{Hg}, \mathrm{Cd}$, and $\mathrm{Cu} ; \mathrm{Hg}, \mathrm{Cd}$, and $\mathrm{Cu} ; \mathrm{Hg}$, $\mathrm{Cd}, \mathrm{Pb}$, and $\mathrm{Cu}$; and $\mathrm{Hg}, \mathrm{Cd}, \mathrm{Zn}, \mathrm{Pb}$, and $\mathrm{Cu}$; as well as $\mathrm{Hg}$, $\mathrm{Cd}$, and $\mathrm{Pb}$, respectively. Meanwhile, the isolates Chn64, Chn91, Chn92, and Chn108 were also resistant to AMP; AMP and RIF; and AMP and RIF; as well as AMP, sulfamethoxazole, and STR, respectively (Song et al. 2013). We hypothesized that there could be high incidence of antimicrobial and/ or heavy metal-resistant $V$. cholerae in freshwater fish. 
In this study, we investigated the virulence, antibiotic, and heavy metal tolerance of $400 \mathrm{~V}$. cholerae strains isolated from four commonly consumed freshwater fish (A. nobilis, $C$. auratus, C. idellus, and P. pekinensis) sampled in July and August of 2017 in Shanghai, China. Additionally, we also obtained and compared fingerprinting profiles of the 400 $V$. cholerae isolates using the ERIC-PCR assay to address their phylogenetic relatedness for better understanding of genome evolution of the bacterium.

\section{Materials and methods}

\section{Sample collection}

The four commonly consumed freshwater fish were sampled in July and August of 2017 from two largest fish markets located in Shanghai, China, including the Jiayan Aquatic Market ( $\left.31^{\circ} 19^{\prime} 57.61^{\prime \prime} \mathrm{N}, 121^{\circ} 10^{\prime} 53.05^{\prime \prime} \mathrm{E}\right)$ and Jiangyang Aquatic Market ( $\left.31^{\circ} 21^{\prime} 25.90^{\prime \prime} \mathrm{N}, 121^{\circ} 26^{\prime} 50.68^{\prime \prime} \mathrm{E}\right)$. Forty fish samples comprising of $A$. nobilis $(n=10)$, C. auratus $(n=$ $10), C$. idellus $(n=10)$, and $P$. pekinensis $(n=10)$ were collected into sterile sealed bags (Nanjing Maojie Microbial Technology Co., Ltd., Nanjing, China), and immediately transported in ice boxes $(700 \times 440 \times 390 \mathrm{~mm})$ to the laboratory in Shanghai Ocean University, Shanghai, China, for analysis.

\section{Isolation of $V$. cholerae}

$V$. cholerae was isolated and identified in accordance with the instructions of the Chinese Government Standard (SN/T 1022-2010) and the Bacteriological Analytical Manual of the US Food and Drug Administration (8th Edition, Revision A, 1998) as described previously (Song et al. 2013). Briefly, $25 \mathrm{~g}$ of each fish intestine sample was rinsed with $225 \mathrm{~mL}$ sterile $1 \times$ phosphate buffer saline (PBS, pH 7.47.6, Shanghai Sangon Biological Engineering Technology and Services Co., Ltd., Shanghai, China), and then homogenized for 2 min using a stomacher (Bagmixer $400 \mathrm{~W}$, Interscience, Saint Nom la Bretèche, France). Serial tenfold dilutions were prepared up to $1: 10^{5}$ dilution, and $100 \mu \mathrm{L}$ of each dilution was spread on thiosulfate citrate bile salts sucrose (TCBS; Beijing Land Bridge Technology Co., Ltd., Beijing, China) agar plates, which were incubated at $37{ }^{\circ} \mathrm{C}$ for $24 \mathrm{~h}$. Yellow, flat, and shiny colonies that were 2 to $3 \mathrm{~mm}$ in diameter on the TCBS agar plates were picked out for further analysis.

\section{Identification of $V$. cholerae}

$V$. cholerae isolates were also identified by biochemical tests, including the arginine dihydrolase test and the esculin hydrolysis test (Choopun et al., 2002; Thornley 1960) using the double-arginine hydrolase medium $(\mathrm{pH}$ $6.8,3.0 \% \mathrm{NaCl})$ and the esculin medium $(\mathrm{pH} 7.3,3.0 \%$ $\mathrm{NaCl}$ ) (Muwei Biotechnology Co., Ltd., Shanghai, China), respectively. After inoculation, the former medium was covered with sterile mineral oil (Shanghai Sangon Biological Engineering Technology and Services Co., Ltd., Shanghai, China), and then incubated at $37{ }^{\circ} \mathrm{C}$ for 24 h. Appearance of a red color was considered as a positive reaction, while the blackening of the latter medium indicated a positive reaction. $V$. cholerae isolates that were detected negative in the two tests, showing deep yellow and brown, respectively, were picked out for the further identification by the PCR assay and DNA sequencing analysis.

The oligonucleotide primers (VHMF and VHA-AS5, Table 1) targeting the $V$. cholerae-specific gene lolB were synthesized by Shanghai Sangon Biological Engineering Technology and Services Co., Ltd. (Shanghai, China). The lolB gene with an expected amplicon size of 516 bp was amplified according to the method described previously (Lalitha et al. 2008) with slight modification. Briefly, PCR reaction mixture contained $8 \mu \mathrm{L}$ of DNase/RNase-free deionized water (Tiangen Biotech Co., Ltd., Beijing, China), $10 \mu \mathrm{L}$ of $2 \times$ Taq Master Mix (Novoprotein Technology Co., Ltd., Shanghai, China), $0.5 \mu \mathrm{L}$ of each primer (VHMF and VHA-AS5), and $1 \mu \mathrm{L}$ of DNA template. PCR was carried out under the following conditions: initial denaturation at $94{ }^{\circ} \mathrm{C}$ for $5 \mathrm{~min}$, followed by 30 cycles consisting of denaturation at $94{ }^{\circ} \mathrm{C}$ for $1 \mathrm{~min}$, annealing at $57{ }^{\circ} \mathrm{C}$ for $1 \mathrm{~min}$, and extension at $72{ }^{\circ} \mathrm{C}$ for $1 \mathrm{~min}$. All PCR reactions were performed in a Mastercycler ${ }^{\circledR}$ pro PCR thermal cycler (Eppendorf, Hamburg, Germany). Amplicons were analyzed by electrophoresis with a $2.0 \%$ agarose gel, and visualized and recorded using a UVP EC3 Imaging system (UVP LLC, Upland, CA, USA). V. cholerae GIM 1.449 (lolB ${ }^{+}$) (Guangdong Culture Collection Center, Guangzhou, China) was used as a positive control strain.

Bacterial 16S ribosomal RNA (rRNA) gene was also amplified using universal bacterial primers $27 \mathrm{~F}$ and 1492R (Weisburg et al. 1991). A $25-\mu \mathrm{L}$ reaction mixture contained $12.5 \mu \mathrm{L}$ of $2 \times$ Taq Master Mix (Novoprotein Technology Co., Ltd., Shanghai, China), $1.25 \mu \mathrm{L}$ of each primer (27F and 1492R), and $1 \mu \mathrm{L}$ of DNA template. The thermal cycler was used at the following setting: initial denaturing at $94{ }^{\circ} \mathrm{C}$ for $3 \mathrm{~min}$, followed by 30 cycles of denaturing at $94{ }^{\circ} \mathrm{C}$ for $40 \mathrm{~s}$, annealing at $55^{\circ} \mathrm{C}$ for $45 \mathrm{~s}$, elongation at $72{ }^{\circ} \mathrm{C}$ for $2 \mathrm{~min}$. The PCR products were analyzed as described above.

The PCR products were purified and sequenced by Shanghai Sangon Biological Engineering Technology 
Table 1 Oligonucleotides used in this study

\begin{tabular}{|c|c|c|c|}
\hline Primer & Sequence $\left(5^{\prime} \rightarrow 3^{\prime}\right)$ & Amplicon size (bp) & Reference \\
\hline $\begin{array}{l}\text { VHMF } \\
\text { VHA-AS5 }\end{array}$ & $\begin{array}{l}\text { TGGGAGCAGCGTCCATTGTG } \\
\text { CAATCACACCAAGTCACTC }\end{array}$ & 516 & Lalitha et al. (2008) \\
\hline $\begin{array}{l}27 \mathrm{~F} \\
1492 \mathrm{R}\end{array}$ & $\begin{array}{l}\text { GAGAGTTTGATCCTGGCTCAG } \\
\text { TACGGCTACCTTGTTACGAC }\end{array}$ & $\sim 1540$ & Weisburg et al. (1991) \\
\hline $\begin{array}{l}\operatorname{ctx} A B-\mathrm{F} \\
\operatorname{ctx} A B-\mathrm{R}\end{array}$ & $\begin{array}{l}\text { TGAAATAAAGCAGTCAGGTG } \\
\text { GGTATTCTGCACACAAATCAG }\end{array}$ & 778 & McGrath et al. (2006) \\
\hline $\begin{array}{l}\text { tcpA-F } \\
\text { tcpA-R }\end{array}$ & $\begin{array}{l}\text { ATGCAATTATTAAAACAGCTTTTTAAG } \\
\text { TTAGCTGTTACCAAATGCAACAG }\end{array}$ & 675 & Kumar et al. (2010) \\
\hline $\begin{array}{l}\text { ace- } \mathrm{F} \\
\text { ace- } \mathrm{R}\end{array}$ & $\begin{array}{l}\text { TAAGGATGTGCTTATGATGGACACCC } \\
\text { CGTGATGAATAAAGATACTCATAGG }\end{array}$ & 316 & Singh et al. (2002) \\
\hline $\begin{array}{l}z o t-\mathrm{F} \\
z o t-\mathrm{R}\end{array}$ & $\begin{array}{l}\text { TCGCTTAACGATGGCGCGTTTT } \\
\text { AACCCCGTTTCACTTCTACCCA }\end{array}$ & 947 & Tulatorn et al. (2018) \\
\hline $\begin{array}{l}r t x A-\mathrm{F} \\
\operatorname{rtxA} x-\mathrm{R}\end{array}$ & $\begin{array}{l}\text { GGGATACAATGCCCTCTGGCA } \\
\text { TGGGTTGGCGGTTGGATTTTAC }\end{array}$ & 977 & Rivera et al. (2001) \\
\hline $\begin{array}{l}r t x B-F \\
r t x B-\mathrm{R}\end{array}$ & $\begin{array}{l}\text { ATTCATTTTTATTTAAGTGTCATCA } \\
\text { TTTCGCTCAGCACTCTTT }\end{array}$ & 400 & This study \\
\hline $\begin{array}{l}r t x C-\mathrm{F} \\
r t x C-\mathrm{R}\end{array}$ & $\begin{array}{l}\text { ATGTCTATTACACATCAACCTGCAA } \\
\text { CGGATACAGCGGTCATTT }\end{array}$ & 437 & This study \\
\hline $\begin{array}{l}r t x D-\mathrm{F} \\
r t x D-\mathrm{R}\end{array}$ & $\begin{array}{l}\text { ATCATGAAGCGTTTCTTTGGTCAAA } \\
\text { CGCCCAAGGTATCAAGAGTCAG }\end{array}$ & 334 & This study \\
\hline $\begin{array}{l}t l h-\mathrm{F} \\
t l h-\mathrm{R}\end{array}$ & $\begin{array}{l}\text { TGGGAGTGGGCAAAGAAT } \\
\text { AAAGGCTATCGCCAAACG }\end{array}$ & 274 & This study \\
\hline $\begin{array}{l}\text { hlyA-F } \\
\text { hlyA-R }\end{array}$ & $\begin{array}{l}\text { CCAAGTGGTGAAGCGGCGGAC } \\
\text { TTCGCTGTTTGCCGGTGCCG }\end{array}$ & 393 & Kumar et al. (2010) \\
\hline $\begin{array}{l}\text { hapA-F } \\
\text { hapA-R }\end{array}$ & $\begin{array}{l}\text { CGTTAGTGCCCATGAGGTC } \\
\text { CGTGACGGCTGATCGAAAT }\end{array}$ & 207 & This study \\
\hline $\begin{array}{l}\text { pilA-F } \\
\text { pilA-R }\end{array}$ & $\begin{array}{l}\text { GCGATTGCAATTCCTCAA } \\
\text { CCTAATGCACCTGATGCT }\end{array}$ & 227 & This study \\
\hline $\begin{array}{l}m s h A-\mathrm{F} \\
m s h A-\mathrm{R}\end{array}$ & $\begin{array}{l}\text { CGCTAGATACTTCGAGTGAG } \\
\text { TACCACAAGCAGTTCCAG }\end{array}$ & 189 & This study \\
\hline $\begin{array}{l}\text { ERIC1R } \\
\text { ERIC2 }\end{array}$ & $\begin{array}{l}\text { ATGTAAGCTCCTGGGGATTCAC } \\
\text { AAGTAAGTGACTGGGGTGAGCG }\end{array}$ & & Rivera et al. (1995) \\
\hline
\end{tabular}

and Services Co., Ltd. (Shanghai, China). DNA sequences were analyzed using the Basic Local Alignment Search Tool (BLAST) of the National Center for Biotechnology Information (NCBI) (available online: https://www.ncbi. nlm.nih.gov/).

\section{Genomic DNA extraction}

V. cholerae isolates were cultured in Luria-Bertani (LB) broth (Beijing Land Bridge Technology Co., Ltd., Beijing, China) ( $\mathrm{pH} 8.5,3.0 \% \mathrm{NaCl}$ ) overnight at $37{ }^{\circ} \mathrm{C}$. Bacterial lysate was prepared according to the method described previously (Letchumanan et al. 2015). Briefly, $5 \mu \mathrm{L}$ of bacterial culture was heated in $50 \mu \mathrm{L}$ of ultrapure water at $95{ }^{\circ} \mathrm{C}$ for $10 \mathrm{~min}$, and then transferred on ice for cooling. After centrifugation at $12,000 \mathrm{rpm}$ for $5 \mathrm{~min}$, the resulting supernatant was used as DNA template for PCR assays.
Detection of virulence and virulence-associated genes

The major virulence genes ( $\operatorname{ctx} A B$ and $t c p A$ ) (Kumar et al. 2010; McGrath et al. 2006) and virulence-associated genes (ace, zot, rtxABCD, hapA, hlyA, tlh, mshA, and pilA) (Singh et al. 2002; Tulatorn et al. 2018) were detected by the PCR assay. PCR reactions were performed as described above, but with different annealing temperatures and elongation times based on melting temperatures of primer pairs and predicted sizes of PCR products. The primers were synthesized as described above. V. cholerae ATCC $14035\left(\operatorname{ctx} A B^{+}, t c p A^{+}, a c e^{+}\right.$, and $\left.z o t^{+}\right)$and GIM $1.449\left(\operatorname{ctx} A B^{-}, r t x A^{+}, r t x B^{+}, r t x C^{+}, r t x D^{+}\right.$, $h l y A^{+}, t l h^{+}$, and $\left.h a p A^{+}\right)$, which were isolated from clinical and environmental cases, respectively, were used as positive control strains as described previously (Boustanshenas et al. 2013). PCR products were confirmed by DNA sequencing at Shanghai Sangon Biological Engineering Technology and Services Co., Ltd. (Shanghai, China). All the oligonucleotide primers used in this study are listed in Table 1. 


\section{Antibiotic susceptibility and heavy metal tolerance assays}

V. cholerae isolates were measured for in vitro susceptibility to ten antimicrobial agents (Oxoid, UK) according to the method described previously (Hu and Chen 2016; Tang et al. 2014). Ten antimicrobial agents were AMP, CHL, KAN, RIF, SPT, STR, TET, TM, and sulfamethoxazole plus trimethoprim (SXT). Tolerance of $V$. cholerae isolates to eight heavy metals $\mathrm{NiCl}_{2}, \mathrm{CrCl}_{3}, \mathrm{CdCl}_{2}, \mathrm{PbCl}_{2}, \mathrm{CuCl}_{2}, \mathrm{ZnCl}_{2}, \mathrm{MnCl}_{2}$, and $\mathrm{HgCl}_{2}$ (Analytical Reagent, Sinopharm Chemical Reagent Co., Ltd, Shanghai, China) was also determined according to the method described previously (Hu and Chen 2016). Escherichia coli strains ATCC25922 and K12 (Institute of Industrial Microbiology, Shanghai, China) were used as quality control strains in antibiotic and heavy metal resistance tests, respectively (Matyar 2012; Song et al. 2013).

\section{ERIC-PCR assay}

Strain taxonomy was determined by ERIC-PCR with the primer set ERIC1R and ERIC2 (Rivera et al. 1995) (Table 1). A $20-\mu \mathrm{L}$ reaction mixture contained $10 \mu \mathrm{L}$ of $2 \times$ Taq Master Mix (Novoprotein Technology Co., Ltd., Shanghai, China), $1 \mu \mathrm{L}$ of each primer, and $2 \mu \mathrm{L}$ of DNA template. The ERIC-PCR was performed under the following conditions: denaturation at $95^{\circ} \mathrm{C}$ for $30 \mathrm{~s}$, annealing at $52^{\circ} \mathrm{C}$ for $1 \mathrm{~min}$, and extension at $65^{\circ} \mathrm{C}$ for $8 \mathrm{~min}$. Following 32 reaction cycles, reaction mixtures were further incubated at 65 ${ }^{\circ} \mathrm{C}$ for an additional $16 \mathrm{~min}$. Six microliters of each amplicon was electrophoresed at $100 \mathrm{~V}$ for about $45 \mathrm{~min}$ on a $1.0 \%$ agarose gel. Amplified DNA fragments were visualized and recorded as described above.

\section{Statistical analysis}

Data analysis was performed using the SPSS statistical analysis software version 17.0 (SPSS Inc., Chicago, USA). The multiple antimicrobial resistance index (MARI) of an isolate is defined as $a / b$, where $a$ represents the number of antibiotics to which the isolate was resistant, and $b$ represents the number of antibiotics to which the isolate was subjected (Krumperman 1983). One-way analysis of variance (ANOVA) followed by appropriate post-hoc test (Tukey) was performed to determine significant differences between the four different fish samples and MARI of resistant isolates, and $P<0.05$ was considered statistically significant. DNA banding patterns generated by the ERIC-PCR were analyzed using the BioNumerics 7.6 software (Meacham et al. 2003). All the PCR fingerprinting profiles were assigned arbitrary designations, and quantitative differences among the profiles were defined using the Dice coefficient. Cluster analysis was carried out based on the unweighted pair group with arithmetic averages (UPGMA) using a position tolerance of 0.5 . The single numerical index of discrimination (D) was based on the probability that two unrelated strains sampled from the test population will be placed into different typing groups. This probability can be calculated by Simpson's index of diversity (Simpson 1972).

\section{Results}

\section{Prevalence of $V$. cholerae in the fish species}

In this study, a total of 3716 yellow single colonies recovered from the 40 freshwater fish samples were randomly picked out from the selective TCBS agar plates for further identification. Approximately $84.0 \%$ (3123/3716) of these colonies were tested negative in either the double-arginine hydrolase test or the esculin hydrolysis test. Moreover, they were detected positive for the $V$. cholerae-specific gene lolB, which is highly conserved for $V$. cholerae (Lalitha et al. 2008). The results were confirmed by DNA sequencing and analysis based on amplicons of the lolB and 16S rRNA genes. Additionally, $64.8 \%(2022 / 3123)$ of the $V$. cholerae isolates originated from the Jiayan aquatic market, and $35.3 \%$ (1101/3123) from the Jiangyang aquatic market. Furthermore, approximately $28.7 \%$ $(n=897), 20.7 \%(n=645), 29.5 \%(n=922)$, and $21.1 \%(n=$ 659 ) of the isolates were recovered from the $C$. auratus, $A$. nobilis, P. pekinensis, and C. idellus samples, respectively.

\section{Virulence and virulence-associated genes in the $V$. cholerae isolates}

Pure culture of randomly selected $100 \mathrm{~V}$. cholerae isolates recovered from each species of the four commonly consumed freshwater fish was analyzed and reported in this study. All the isolates were detected positive for the V. cholerae-specific lolB gene, but negative for the toxin genes $\operatorname{ctx} A B$, ace, zot, and tcpA (Fig. 1). In contrast, high occurrence of the virulenceassociated genes $\operatorname{rtxABCD}(83.0 \%, 97.0 \%, 95.8 \%$, and $95.5 \%$, respectively), hlyA (87.8\%), th $(76.0 \%)$, and hapA (95.0\%) was observed in the $400 \mathrm{~V}$. cholerae isolates, whereas low percentages of the pilA $(0.8 \%)$ and $m s h A(0.8 \%)$ genes were detected (Fig. 1).

As illustrated in Fig. 1, the V. cholerae isolates recovered from the four freshwater fish species had similar toxic genotypes; the most of which were featured with the rtxA, th, hlyA, and hapA genes (75.0-100.0\%), except a lower percentage of rtxA gene in A. nobilis (61.0\%). However, the pilA gene was only detected from two isolates derived from $C$. auratus and one from A. nobilis. The $m s h A$ gene was only present in three isolates, which were recovered from A. nobilis, C. idellus, and P. pekinensis, respectively. 
Fig. 1 Virulence profiles of the $400 \mathrm{~V}$. cholerae isolates recovered from the four fish species

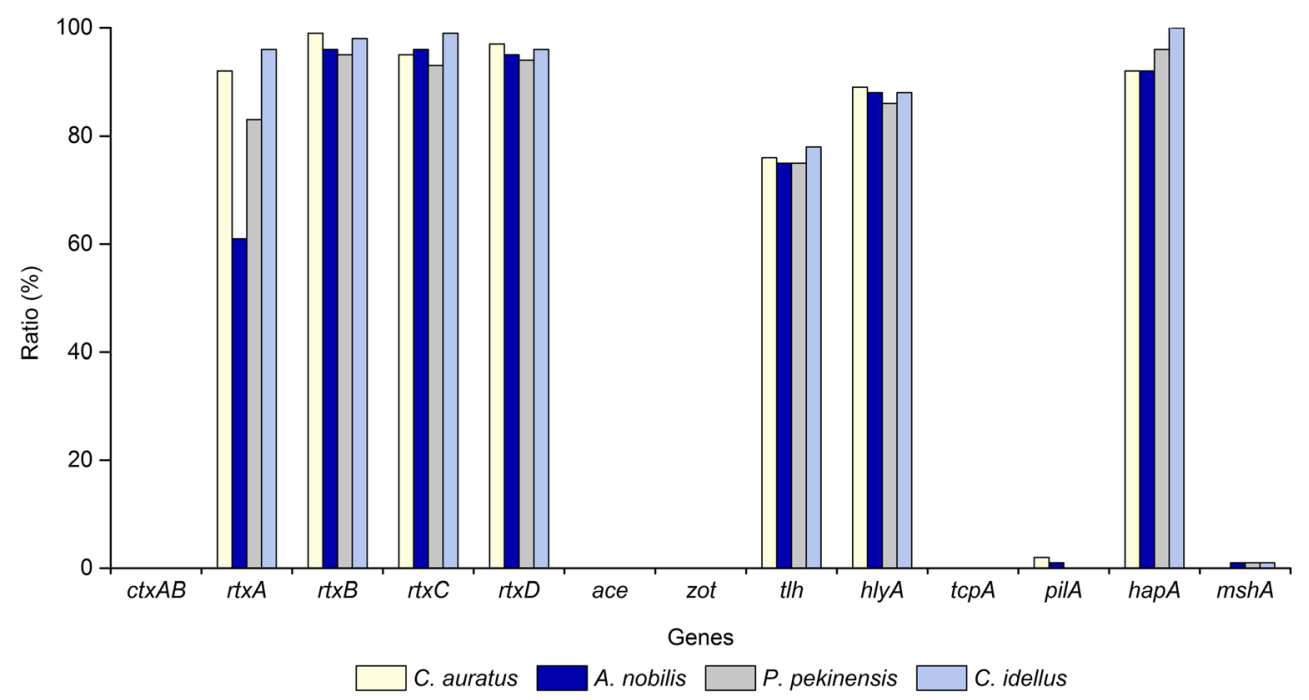

\section{Antimicrobial resistance profiles of the $V$. cholerae isolates}

We determined antimicrobial susceptibility in vitro of the $400 \mathrm{~V}$. cholerae isolates to ten antimicrobial agents, and the resulting data were illustrated in Fig. 2 (Table S1). Approximately $15.3 \%$ of the isolates were susceptible to all the ten antimicrobial drugs evaluated. Moreover, most isolates were also sensitive to $\mathrm{CN}$ (98.3\%), CHL (98.0\%), and SPT (95.0\%). In contrast, the STR resistance was the most predominant $(65.3 \%)$ among the $V$. cholerae isolates, followed by AMP (44.5\%) and RIF (24.0\%). Approximately $72.3 \%, 39.5 \%$, and $34.3 \%$ of the isolates also exhibited intermediate susceptibility to KAN, RIF, and TET. The resistance trend of the $400 \mathrm{~V}$. cholerae

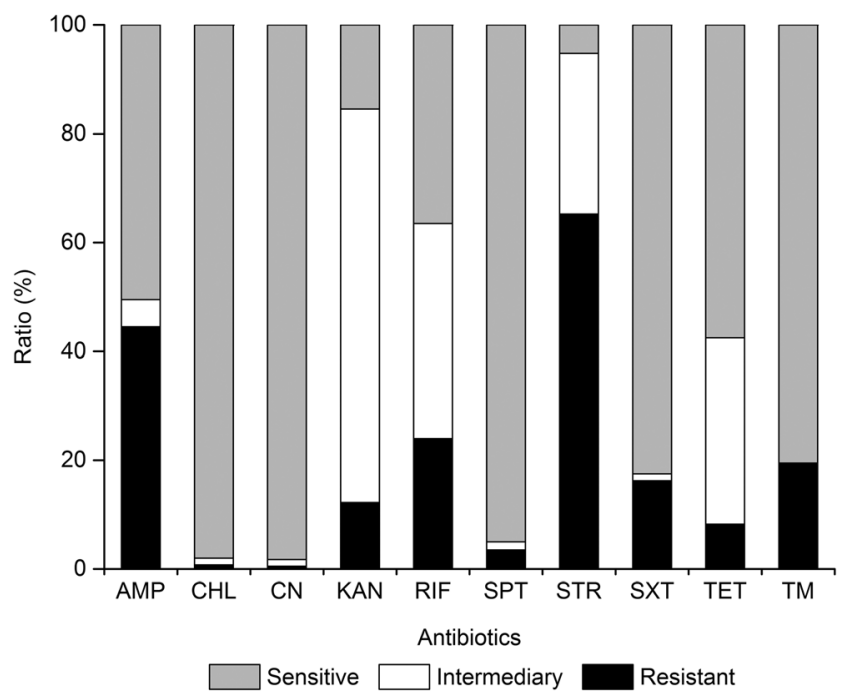

Fig. 2 Antimicrobial susceptibility profiles of the $400 \mathrm{~V}$. cholerae isolates evaluated in this study. AMP ampicillin, $C H L$ chloramphenicol, $C N$ gentamicinm, $K A N$ kanamycin, $R I F$ rifampicin, $S P T$ spectinomycin, $S T R$ streptomycin, SXT sulfamethoxazole-trimethoprim, TET tetracycline, $T M$ trimethoprim isolates was $\mathrm{STR}>\mathrm{AMP}>\mathrm{RIF}>\mathrm{TM}>\mathrm{SXT}>\mathrm{KAN}>$ $\mathrm{TET}>\mathrm{SPT}>\mathrm{CHL}>\mathrm{CN}$.

Our data also revealed different antimicrobial-resistant profiles for the $V$. cholerae isolates recovered from different fish species (Fig. 3). The isolates from C. idellus had a higher proportion of resistance to STR $(75.0 \%)$ than those isolates recovered from $C$. auratus $(67.0 \%)$, P. pekinensis (65.0\%), and A. nobilis $(54.0 \%)$. About half of A. nobilis (54.0\%) and $C$. auratus $(53.0 \%)$ isolates were also resistant to AMP, which were higher than those isolates from C. idellus (38.0\%) and P. pekinensis (33.0\%). Meanwhile, the TM, SPT, and SXT-resistant $V$. cholerae isolates from C. auratus were $34.0 \%, 5.0 \%$, and $28.0 \%$, respectively, which were higher than those observed in A. nobilis (9.0\%, 2.0\%, and $8.0 \%)$, P. pekinensis $(19.0 \%, 3.0 \%$, and $14.0 \%)$, and $C$. idellus $(16.0 \%, 4.0 \%$, and $15.0 \%)$. Additionally, a few isolates from $C$. idellus and $C$. auratus were also resistant to $\mathrm{CN}$ and or $\mathrm{CHL}$, whereas none of the isolates from the other two fish species were resistant to these two drugs.

In this study, approximately $30.5 \%(n=122)$ of the isolates exhibited MDR phenotypes (Ling et al. 1983), which varied depending on the fish species. The strains isolated from $C$. auratus showed the highest occurrence of MDR (42.0\%), followed by $34.0 \%, 31.0 \%$, and $15.0 \%$ from the $C$. idellus, P. pekinensis, and A. nobilis, respectively. The values of MARI of the $400 \mathrm{~V}$. cholerae isolates ranged from 0.00 to 0.70 , indicating varying degrees of exposing to the antimicrobial agents evaluated. Forty-two different resistance patterns with a significantly different MARI $(>0.20)$ were observed. Two isolates recovered from $C$. idellus had the highest MARI of 0.70 , and displayed resistance to seven of the ten antimicrobial agents tested. Additionally, the mean MARI values for the $V$. cholerae isolates recovered from $C$. auratus, A. nobilis, $P$. pekinensis, and $C$. idellus were $0.24,0.16,0.18$, and 0.21 , respectively, suggesting a significantly different antibiotic 
Fig. 3 Antimicrobial resistance profiles of $V$. cholerae in the four fish species

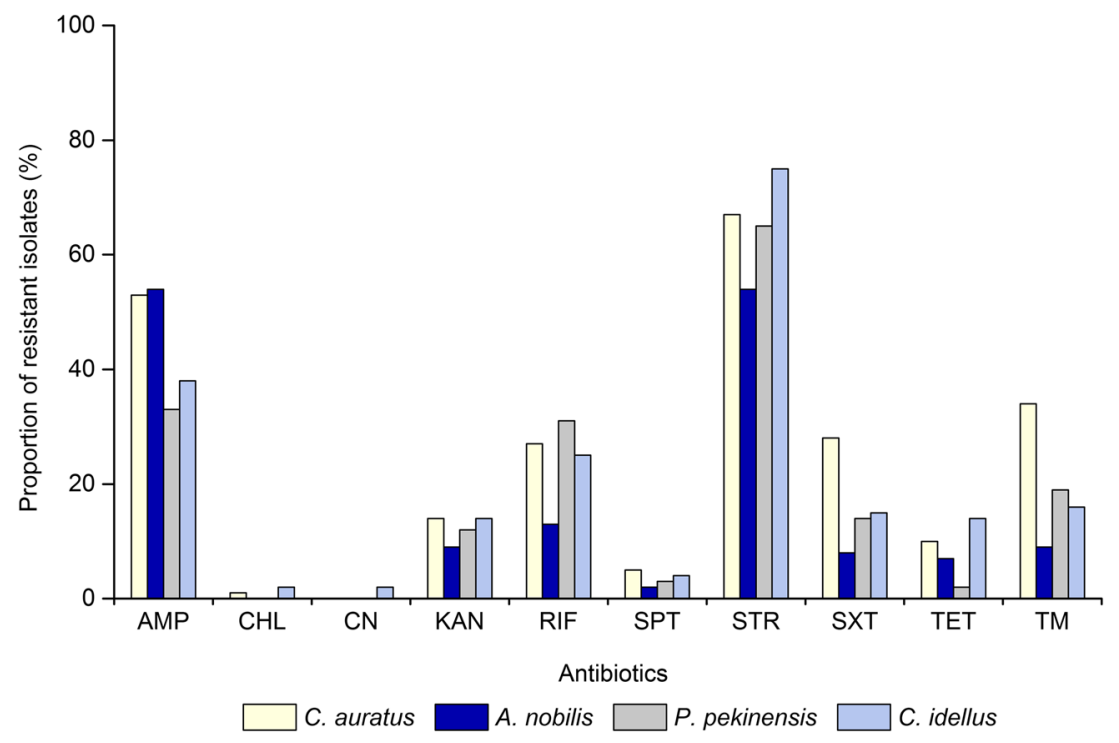

resistant $V$. cholerae population in the four fish species $(P=$ $0.001)$.

\section{Heavy metal tolerance profiles of the $V$. cholerae isolates}

Tolerance of the $400 \mathrm{~V}$. cholerae isolates to eight heavy metals was also determined (Table 2). The maximum MICs observed in the tested isolates were $3200 \mu \mathrm{g} / \mathrm{mL}$ for $\mathrm{Pb}^{2+} ; 1600 \mu \mathrm{g} / \mathrm{mL}$ for $\mathrm{Cr}^{3+}, \mathrm{Mn}^{2+}$, and $\mathrm{Ni}^{2+} ; 800$ $\mu \mathrm{g} / \mathrm{mL}$ for $\mathrm{Cd}^{2+}, \mathrm{Zn}^{2+}$, and $\mathrm{Hg}^{2+}$; and $400 \mu \mathrm{g} / \mathrm{mL}$ for
$\mathrm{Cu}^{2+}$, when compared with the quality control strain E. coli K12 (Malik and Aleem 2011). Many isolates were also tolerant to $\mathrm{Hg}^{2+}(49.3 \%), \mathrm{Zn}^{2+}(30.3 \%)$, and $\mathrm{Pb}^{2+}$ $(12.0 \%)$, and a few isolates resistant to $\mathrm{Cd}^{2+}(4.8 \%)$, $\mathrm{Cr}^{3+}(1.5 \%)$, and $\mathrm{Ni}^{2+}(0.3 \%)$. In contrast, all the isolates were non-resistant to $\mathrm{Cu}^{2+}$ and $\mathrm{Mn}^{2+}$. The tolerance trend of the $400 \mathrm{~V}$. cholerae isolates was $\mathrm{Hg}^{2+}>\mathrm{Zn}^{2+}>\mathrm{Pb}^{2+}>$ $\mathrm{Cd}^{2+}>\mathrm{Cr}^{3+}>\mathrm{Ni}^{2+}>\mathrm{Cu}^{2+}=\mathrm{Mn}^{2+}$.

As shown in Fig. 4, the V. cholerae isolates recovered from the four freshwater fish species had different heavy metal tolerance profiles. About half of the isolates from C. auratus

Table 2 Heavy metal tolerance of the $400 \mathrm{~V}$. cholerae isolates evaluated in this study

\begin{tabular}{|c|c|c|c|c|c|c|c|c|c|c|c|c|c|}
\hline \multirow[t]{2}{*}{ Heavy metal } & \multicolumn{11}{|c|}{ Number of isolates with a maximum observed $\mathrm{MIC}(\mu \mathrm{g} / \mathrm{mL})$} & \multicolumn{2}{|c|}{ Resistance } \\
\hline & 3.125 & 6.25 & 12.5 & 25 & 50 & 100 & 200 & 400 & 800 & 1600 & 3200 & No. & $(\%)$ \\
\hline \multirow[t]{2}{*}{$\mathrm{Cd}^{2+}$} & & & & & & & a & & & & & & \\
\hline & & 1 & 1 & 5 & 25 & 153 & 196 & 13 & 6 & & & 19 & 4.8 \\
\hline \multirow[t]{2}{*}{$\mathrm{Cr}^{3+}$} & & & & & & & & & a & & & & \\
\hline & & & & & & & & 13 & 381 & 6 & & 6 & 1.5 \\
\hline \multirow[t]{2}{*}{$\mathrm{Cu}^{2+}$} & & & & & & & & $\mathrm{a}$ & & & & & \\
\hline & & & & & 5 & 101 & 252 & 42 & & & & 0 & 0.0 \\
\hline \multirow[t]{2}{*}{$\mathrm{Hg}^{2+}$} & & $\mathrm{a}$ & & & & & & & & & & & \\
\hline & 80 & 123 & 113 & 69 & 12 & & 2 & & 1 & & & 197 & 49.3 \\
\hline \multirow[t]{2}{*}{$\mathrm{Mn}^{2+}$} & & & & & & & & & & $\mathrm{a}$ & & & \\
\hline & & & & & & 107 & 251 & 16 & 22 & 4 & & 0 & 0.0 \\
\hline \multirow[t]{2}{*}{$\mathrm{Ni}^{2+}$} & & & & & & & & & $\mathrm{a}$ & & & & \\
\hline & & & 1 & & 1 & 15 & 320 & 60 & 2 & 1 & & 1 & 0.3 \\
\hline \multirow[t]{2}{*}{$\mathrm{Pb}^{2+}$} & & & & & & & & & $\mathrm{a}$ & & & & \\
\hline & & & & & & & 1 & 1 & 350 & 47 & 1 & 48 & 12.0 \\
\hline \multirow[t]{2}{*}{$\mathrm{Zn}^{2+}$} & & & & & & & $\mathrm{a}$ & & & & & & \\
\hline & & & & 1 & & 63 & 215 & 112 & 9 & & & 121 & 30.3 \\
\hline
\end{tabular}

${ }^{\mathrm{a}}$ Minimal inhibition concentration of the standard quality control strain E. coli K12 
Fig. 4 Heavy metal tolerance profiles of $V$. cholerae in the four fish species

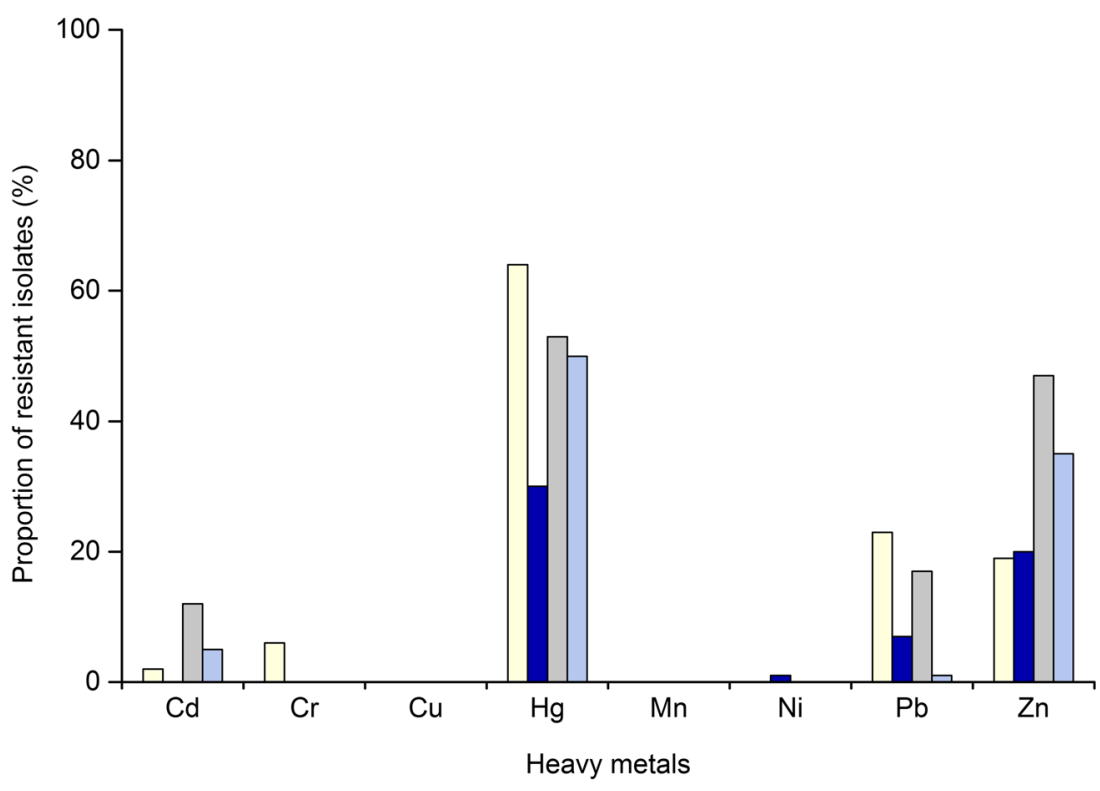

C. auratus P. pekinensis C. idellus
(64.0\%), P. pekinensis (53.0\%), and C. idellus $(50.0 \%)$ showed resistance to $\mathrm{Hg}^{2+}$, and a lower percentage from A. nobilis (30.0\%). Approximately $47.0 \%$ and $35.0 \%$ of the isolates from $P$. pekinensis and $C$. idellus were tolerant to $\mathrm{Zn}^{2+}$, respectively, while $20.0 \%$ and $19.0 \%$ from A. nobilis and $C$. auratus tolerant to this heavy metal, respectively. Moreover, the isolates from $C$. auratus showed the highest proportion of $\mathrm{Pb}^{2+}$-resistance $(23.0 \%)$, followed by $17.0 \%$ from $P$. pekinensis, $7.0 \%$ from $A$. nobilis, and $1.0 \%$ from $C$. idellus. The highest percentage of $\mathrm{Cd}^{2+}$-resistant isolates (12.0\%) was observed from P. pekinensis, followed by $5.0 \%$ from $C$. idellus and $2.0 \%$ from $C$. auratus, but all of the isolates from A. nobilis were susceptible to this heavy metal. It is noteworthy that all of the $\mathrm{Cr}^{3+}$ - and $\mathrm{Ni}^{2+}$-resistant isolates (6.0\% and $1.0 \%)$ were recovered from $C$. auratus and A. nobilis, respectively.

\section{Genetic diversity of the $V$. cholerae isolates}

The ERIC-PCR was used to investigate genetic diversity of the $400 \mathrm{~V}$. cholerae isolates recovered from the four fish species. The obtained fingerprinting profiles comprised various numbers of DNA bands mainly ranging from 100 to $5000 \mathrm{bp}$, among which a 500-bp band was shared by all the isolates (Figure S1). Based on the fingerprinting profiles, all the isolates were classified into 328 different ERIC-genotypes, $86.9 \%(n=285)$ of which were assigned as singletons. Approximately $27.0 \%(n=77), 26.0 \%(n=74), 24.6 \%(n=$ $70)$, and $22.4 \%(n=64)$ of these singletons were derived from A. nobilis, C. auratus, $P$. pekinensis, and $C$. idellus, respectively. The UPGMA algorithm grouped all the 328 ERICgenotypes into 12 distinct clusters at a $22.0 \%$ similarity cut- off level (Figure S1). About half (47.8\%) of the 400 $V$. cholerae isolates were grouped into Cluster 5, while $20.5 \%(n=82)$ were distributed into Cluster $6(10.8 \%, n=$ $43)$ and Cluster $11(9.8 \%, n=39)$, and the remaining $(31.8 \%$, $n=127$ ) were classified into Clusters 1 to 4,7 to 10 , and 12 with percentages in the range from 5.5 to $1.5 \%$ (Figure S1). Most isolates had the similarity coefficient of $30.0-90.0 \%$, and the Simpson's diversity index was 0.9987 . These results demonstrated high genetic diversity of the $400 \mathrm{~V}$. cholerae isolates recovered from the four fish species.

On the other hand, approximately $28.8 \%(n=115)$ of the $400 \mathrm{~V}$. cholerae isolates shared 43 ERIC-genotypes (Table S2), most of which were grouped into Cluster 5 $(65.1 \%, n=28)$. Among these 115 isolates, approximately $31.3 \%(n=36)$ were recovered from $C$. idellus, followed by $26.1 \%(n=30), 22.6 \%(n=26)$, and $20.0 \%(n=23)$ from $P$. pekinensis, $C$. auratus, and A. nobilis, respectively. For instance, the most predominant ERIC-genotype vc00124 was derived from $C$. idellus $(5.2 \%, n=6)$, suggesting likely near-present relatives or clonal relatedness. Likewise, the ERIC-genotypes $v c 00129(3.5 \%, n=4)$, $v c 00307(3.5 \%, n=4)$, and $v c 00148(3.5 \%, n=4)$ were derived from the $V$. cholerae isolates from $C$. idellus, C. idellus, and A. nobilis, respectively. Moreover, there were 15 genotypes $(34.9 \%, n=15)$ shared by the isolates derived from different fish species, suggesting possible interspecies transmission of $V$. cholerae. For instance, five isolates shared the identical genotype $v c 00067$, three of which were recovered from $C$. auratus (C. auratus0250, C. Auratus 02-65, and $C$. auratus 02-22), and two from A. nobilis (A. nobilis10-63) and P. pekinensis (P. pekinensis 08-05), respectively. 


\section{Comparison of the MDR and heavy metal tolerance}

The $122 \mathrm{~V}$. cholerae isolates with MDR phenotypes were further analyzed, and the resulting data revealed the great genetic diversity with the Simpson's diversity index of 0.9970 (Fig. 5). These MDR isolates belonging to 106 ERIC-genotypes were classified into four distinct clusters, designated as Cluster $\alpha, \beta, \gamma$, and $\delta$. The majority of the MDR isolates were grouped into Cluster $\beta(68.0 \%, n=83)$ with 70 ERIC-genotypes, about $43.4 \%(n=36), 26.5 \%(n=22), 15.6 \%(n=13)$, and $14.5 \%(n=12)$ of which were recovered from C. auratus, P. pekinensis, A. nobilis, and C. idellus, respectively. Cluster $\alpha$ was the second largest cluster $(13.1 \%, 16 / 122)$ and consisted of 16 MDR isolates with 16 ERIC-genotypes, while the Cluster $\delta$ also contained 16 isolates and Cluster $\gamma$ had only seven MDR isolates. Among the 122 MDR isolates, about half $(51.6 \%, n=63)$ were tolerant to one heavy metal, and $16.4 \%(n=20)$ and $5.7 \%(n=7)$ were tolerant to two and three heavy metals, respectively. Different resistance profiles were observed in different phylogenetic clusters. For instance, the $\mathrm{Hg} / \mathrm{AMP} / \mathrm{RIF} / \mathrm{STR}$ resistance profile was the most predominant in Cluster $\alpha(25.0 \%, 4 / 16)$, followed by the Hg/AMP/ STR/TM $(18.8 \%, 3 / 16)$ and $\mathrm{Hg} / \mathrm{AMP} / \mathrm{STR} / \mathrm{SXT}$ resistance profiles $(12.5 \%, 2 / 16)$. In Cluster $\beta$, approximately $27.7 \%$ (23/83) of the isolates exhibited resistance to $\mathrm{Hg} / \mathrm{STR} / \mathrm{SXT} /$ $\mathrm{TM}$, followed by $\mathrm{Hg} / \mathrm{AMP} / \mathrm{RIF} / \mathrm{STR}(20.5 \%, 17 / 83)$ and $\mathrm{Hg} /$ AMP/STR/TM $(18.1 \%, 15 / 83)$. The isolates in Cluster $\gamma$ had the $\mathrm{Hg} / \mathrm{AMP} / \mathrm{KAN} / \mathrm{STR}(28.6 \%, 2 / 7)$ and $\mathrm{Hg} / \mathrm{AMP} / \mathrm{KAN} /$ RIF resistance profiles $(14.3 \%, 1 / 7)$, while two major resistance profiles $\mathrm{Hg} / \mathrm{AMP} / \mathrm{RIF} / \mathrm{STR}(31.3 \%, 5 / 16)$ and $\mathrm{Zn} / \mathrm{AMP} /$ SXT/TM $(18.8 \%, 3 / 16)$ were observed in Cluster $\delta$.

Additionally, 89.6\% ( $n=95)$ of the 106 ERIC-genotypes were assigned as singletons. Among these singletons, approximately $35.8 \%(n=34), 28.4 \%(n=27), 22.1 \%(n=21)$, and $13.7 \%(n=13)$ were derived from C. auratus, C. idellus, P. pekinensis, and A. nobilis, respectively. The MDR isolates with the identical ERIC-genotypes had the similar resistance profiles. For instance, two isolates (C. auratus $02-25$ and $P$. pekinensis09-76) recovered from $C$. auratus and P. pekinensis had the identical ERIC-genotype $v c 00036$, and showed similar resistance to five antimicrobial agents (KAN/ SPT/STR/SXT/TM) and one heavy metal (Hg) (Table S2).

Taken together, these data demonstrated the considerable genetic diversity of the 122 MDR $V$. cholerae isolates, as well as the close relatedness of resistance phenotypes between MDR and heavy metals.

\section{Discussion}

V. cholerae is a leading waterborne pathogen worldwide. Continuous monitoring of $V$. cholerae contamination in aquatic products and identification of risk factors (e.g., virulence and transmissibility of antimicrobial resistance and heavy metal tolerance) are crucial for assuring food safety. To date, a few studies have been conducted to characterize $V$. cholerae in fish (Lan and Love 2012; Runft et al. 2014; Senderovich et al. 2010; Traore et al. 2014; Zago et al. 2017). In this study, V. cholerae was isolated and characterized from the four commonly consumed freshwater fish (A. nobilis, C. auratus, C. idellus, and $P$. pekinensis). To our knowledge, $V$. cholerae has not been previously detected for $A$. nobilis and P. pekinensis.

Our data revealed none occurrence of epidemic V. cholerae $\left(c t x A B^{+} t c p A^{+}\right)$in the fish samples evaluated in this study, consistent with some previous reports showing that neither $c t x A$ nor tcpA is commonly expressed in environmental strains of V. cholerae (Traore et al. 2014; You et al. 2008). Virulence factors associated with the CTX element, such as zot and ace, were also rarely found in $V$. cholerae isolates of environmental water origin (Akoachere and Mbuntcha 2014; Bakhshi et al. 2009). For example, $\mathrm{Li}$ et al. isolated $16 \mathrm{~V}$. cholerae strains from water samples collected at epidemic sites of a 2005 cholera outbreak occurred in the Nansha District of Guangzhou in China, and found that all the isolates were negative for either both $c t x A$ and $t c p A$ or all the four genes $c t x A$, tcpA, ace, and $z o t$, except for one strain that was positive for all four genes ( $\mathrm{Li}$ et al. 2015). Recently, Zago et al. also reported that none of 53 $V$. cholerae strains (non-O1/O139) isolated from ornamental fish species in Italy contained ctxA, zot, and ace. Most of the fish originated from South-East Asian countries between 2000 and 2015 (Zago et al. 2017). These reports were consistent with our findings regarding the ace and zot genes detected in the 400 $V$. cholerae isolates in this study. Previous studies have also shown that $V$. cholerae strains isolated from the environment have other virulence-associated genes such as $r t x A$ and $h l y A$ (Halder et al. 2017; Kumar et al. 2010). The RTX toxin gene cluster $(r t x A B C D)$ is essential for the cytotoxic activity of $V$. cholerae $\mathrm{O} 1 \mathrm{El}$ Tor strain upon Hep-2 cells in vitro test (Lin et al. 1999). The extracellular pore-forming toxin hemolysin (HlyA) can be produced by biotype El Tor of serogroup O1 and most of the non-O1/O139 strains, and has various biological activities (Benitez and Silva 2016; Gao et al. 2018). Recently, Zago et al. reported that $31.5 \%(n=17)$ and $18.5 \%$ $(n=10)$ of $V$. cholerae strains isolated from ornamental fish species carried the $r t x A$ and $h l y A$ genes, respectively (Zago et al. 2017). In this study, our data revealed high percentages of the $r t x A$ (83.0\%), $r t x B$ (97.0\%), rtxC (95.8\%), and $r t x D(95.5 \%)$ genes, as well as the hlyA gene (87.8\%) in the $400 \mathrm{~V}$. cholerae isolates recovered from the four fish species. The th geneencoding protein has phospholipase and lecithinase activity (Fiore et al. 1997). In this study, the th gene was detected positive in $76.0 \%$ of the $400 \mathrm{~V}$. cholerae isolates. V. cholerae produces at least three morphologically distinct types of pili. Except for the TCP, the MSHA pili of $V$. cholerae is used to adhere to zooplankton exoskeletons as a survival strategy in the 


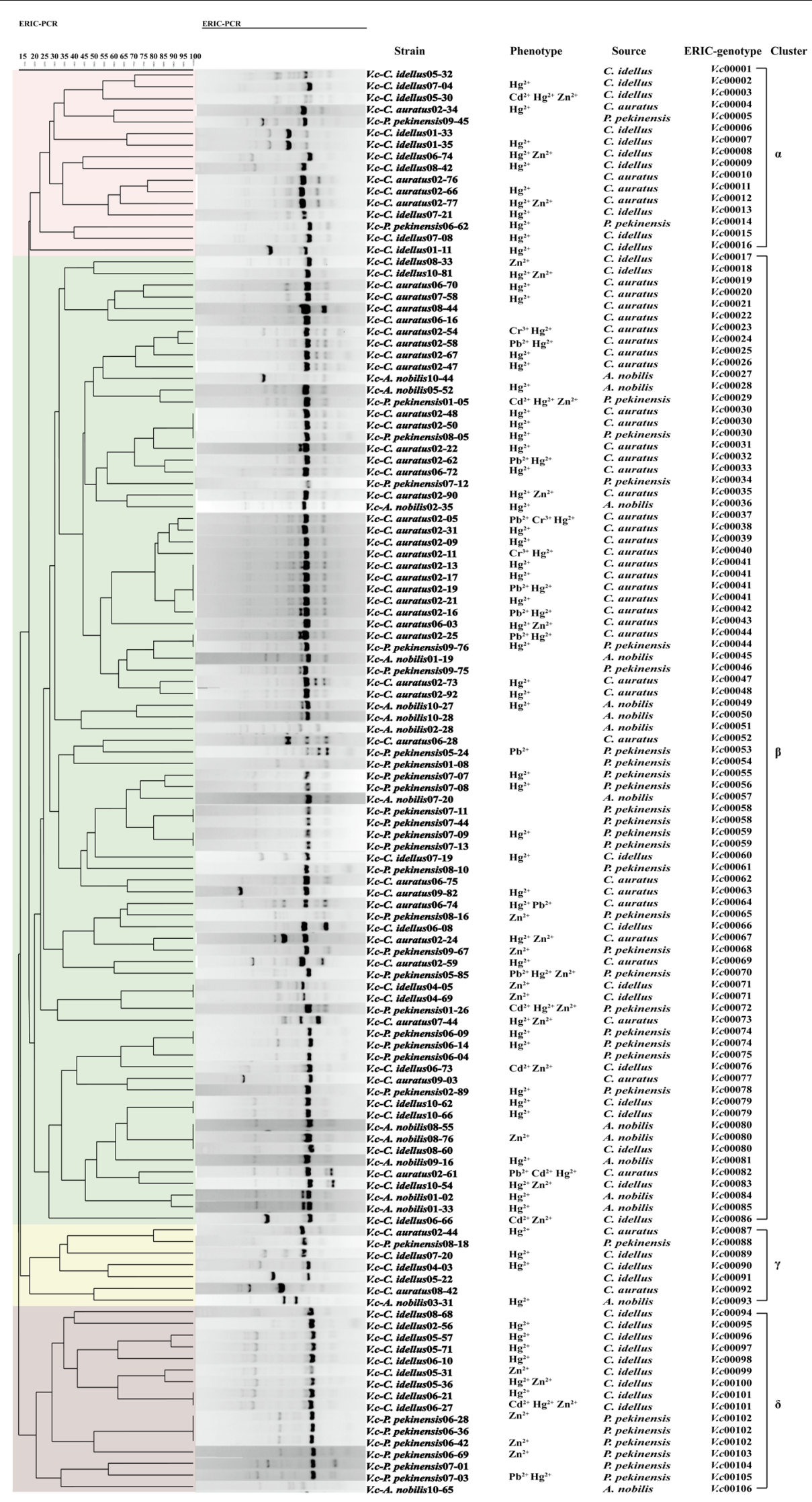

Fig. 5 The ERIC-PCR fingerprinting profiles of the MDR V. cholerae isolates 
aquatic environment (Moorthy and Watnick 2004; Chiavelli et al. 2001). The third type of pili is encoded by a 5.4-kb pil gene cluster that resembles the tap gene cluster in Aeromonas hydrophila and other type IV-A pilus assembly operons in bacteria (Fullner and Mekalanos 1999). In this study, the mshaA and pilA genes were present in $0.8 \%$ and $0.8 \%$ of the 400 $V$. cholerae isolates, respectively. Additionally, the hapA gene encodes a hemagglutinin protease, and plays an important role in $V$. cholerae interaction with aquatic hosts (Halpern et al. 2003). Previous research has indicated that $98.0 \%$ of $V$. cholerae strains carried the hap gene irrespective of their source, i.e., clinical or environmental (Hasan et al. 2013). Recently, Jiang et al. reported that all three $V$. cholerae strains isolated from hepatitis B cirrhosis patients in China harbored pathogenicity-related genes $r t x A, r t x C$, toxR, hapA, hlyA, and ompW, but lacked ctxA, ctxB, tcpA, ompU, and zot genes (Jiang et al. 2018). In this study, approximately $95.0 \%$ of the 400 $V$. cholerae isolates originated from the four fish species were detected positive for the hapA gene. Taken together, our data in this study revealed an extremely low occurrence of pathogenic $V$. cholerae carrying the major virulence genes $c t x A B(0.0 \%)$, tcpA $(0.0 \%)$, ace $(0.0 \%)$, and zot $(0.0 \%)$, as well as potential toxin genes $m s h A(0.8 \%)$ and pilA $(0.8 \%)$. However, high incidence of virulence-associated genes was observed, including the RTX toxin gene cluster $(r t x A-D)(83.0-97.0 \%)$, hlyA (87.8\%), th (76.0\%), and hapA (95.0\%).

Since the mid-1980s, MDR has considerably increased in toxicogenic V. cholerae (Ghosh and Ramamurthy 2011; Kitaoka et al. 2011). In this study, approximately $30.5 \%$ of the $400 \mathrm{~V}$. cholerae isolates recovered from the four fish species had MDR phenotypes, and two isolates derived from C. idellus were resistant to the highest number of antimicrobial agents (7 of 10). The MARI is often used to determine the antibiotic resistance-associated health risk (Fri et al. 2018). In this study, the identified 42 resistance patterns had a significantly different MARI ( $>0.20$ ), indicating different antimicrobial exposure levels or contaminated source. Furthermore, the significant difference in antimicrobial resistance profiles among the four fish samples was also observed (MARI, $P=0.001$ ), suggesting that $C$. auratus was likely exposed to antimicrobial drugs mostly. Additionally, STR $(65.3 \%)$ resistance was very prevalent among the $V$. cholerae isolates, many of which were also resistant to AMP (44.5\%) or RIF (24.0\%). Baron et al. also reported high levels of resistance to STR (22.2\%) and AMP (9.1\%) among $99 \mathrm{~V}$. cholerae strains (non-O1/O139) isolated from wastewater and shellfish in 2000/2001 in the La Rance estuary (Brittany, France) (Baron et al. 2017). High percentages of resistance to STR were also detected among toxigenic (97.9\%) and non-toxigenic O139 strains (88.0\%) isolated in China from 1993 to 2009 (Yu et al. 2012). In fact, antimicrobial agents such as STR, AMP, and sulfisoxazone have been frequently used in agriculture for the last some decades, and STR was the commonly used antibiotic to prevent fish diseases (Yilmaz and Sova
2018). Therefore, the high proportion of resistance of $V$. cholerae to STR could be facilitated by the selective pressure. Previous studies have also revealed high percentages of AMPresistant $V$. cholerae. For example, Thapa Shrestha et al. reported that all the $24 \mathrm{~V}$. cholerae isolates derived from the clinical and water samples were resistant to AMP (Thapa Shrestha et al. 2015). Recently, Ahmed et al. also reported that the AMPresistant percentage of $V$. cholerae strains in clinical and aquatic Vibrio spp. isolates was $100.0 \%$, suggesting intrinsic resistance of Vibrio spp. to AMP (Ahmed et al. 2018). The AMP-resistant bacteria may be attributed to the abuse of drugs and the inappropriate release of industrial wastes into the environment (Taviani et al. 2008). In this study, the low occurrence of the resistance to $\mathrm{CN}(0.5 \%)$ and CHL $(0.8 \%)$ was observed in the $V$. cholerae isolates. It has also been reported that none of the 42 $V$. cholerae isolates recovered from shrimp collected in 2013 and 2014 in Shanghai, China, were resistant to CHL (He et al. 2015). The low percentage of CHL-resistant isolates may be explained by the drug and its salts and esters (including chloramphenicol succinate) have been banned from the animal breeding industry in China (China Department of Agriculture, Bulletin No.193). TET, sulfonamides, and quinolones are widely used in aquaculture. In this study, the resistance to TET was detected positive in $8.3 \%$ of the $400 \mathrm{~V}$. cholerae isolates. It has been reported that about $11 \%$ of $550 \mathrm{~V}$. cholerae O1 El Tor strains isolated from the seventh cholera pandemic in China from 1961 to 2010 were resistant to TET (Wang et al. 2012). Recently, Ottaviani et al. also reported a lower incidence of the TET resistance in $V$. cholerae strains ( 3 of 42 ) isolated from the sea food, sea water, and fresh water in Italy (Ottaviani et al. 2018). Additionally, in this study, the high percentages of intermediate susceptibility to KAN (72.3\%), RIF (39.5\%), and TET (34.3\%) may suggest a potential resistance trend for these drugs.

The rapid development of industrialization, urbanization, and agricultural modernization during recent decades has resulted in the increasing pollution, such as heavy metals, in both freshwater and marine environment (Devlin 2006; Sun et al. 2018). Heavy metals have been detected from sediments of the fish farming environment (He et al. 2012), which could finally be taken into humans through food chain (RamirezPerez et al. 2004; Sawasdee and Kohler 2010). High occurrence of resistance to heavy metals has been reported in Pseudomonas spp. isolated from the environment (e.g., marine, river, and agricultural soil) (Malik and Aleem 2011). Nevertheless, very few studies have been conducted to address heavy metal tolerance of $V$. cholerae originated from the $\mathrm{CNCO}$ particularly from fish. In this study, for the first time, our data revealed that $49.3 \%, 30.3 \%$, and $12.0 \%$ of the $400 \mathrm{~V}$. cholerae isolates recovered from the four commonly consumed freshwater fish species were tolerant to $\mathrm{Hg}^{2+}, \mathrm{Zn}^{2+}$, and $\mathrm{Pb}^{2+}$, respectively. Xing et al. also reported that in the turbot gastrointestinal metagenome, cobalt-zinc-cadmium resistances were one of the 
largest categories of resistance to the toxic compound subsystem (Xing et al. 2013). In this study, about $24.0 \%$ of the 400 $V$. cholerae isolates were resistant to two or more heavy metals, and one $V$. cholerae isolate derived from $C$. auratus was resistant to the highest number of heavy metals (4 of 8). These data suggested heavy metal contamination in the aquacultural environment, which may originate from industrial pollutions, runoffs from farmlands, or hospital waste that finally ends up in rivers and estuaries. Furthermore, the $V$. cholerae isolates from the four fish species had different heavy metal tolerance patterns, suggesting varying degrees of the exposure to the heavy metals evaluated.

The ERIC-PCR has widely been applied to analyze bacterial genotyping in epidemiology (Ranjbar et al. 2010). It has also been used for the analysis of clonal diversity and genotypic variability of $V$. cholera strains from aquatic environment (Goel and Jiang 2011; Rivera et al. 1995). Previous studies reported that ERIC-PCR yielded one to eight DNA amplicons in the size ranging from 100 to $4000 \mathrm{bp}$ (Rivera et al. 1995; Colombo et al. 1997). In this study, the established ERIC-PCR condition generated the amplicons mainly ranged from 100 to $5000 \mathrm{bp}$ in size. Moreover, in this study, the 400 $V$. cholerae isolates were differentiated into 328 ERICgenotypes $(82.0 \%)$, which was more than 179 pulsotypes (71.6\%) from $250 \mathrm{~V}$. cholerae isolates, and 218 pulsotypes (38.4\%) from $568 \mathrm{~V}$. cholerae isolates based on NotI-PFGE (pulsed-field gel electrophoresis) genotyping technique (Gu et al. 2014; Lu et al. 2017). These data demonstrated the considerable genetic diversity of the $400 \mathrm{~V}$. cholerae isolates recovered from the four freshwater fish species.

Previous research highlighted that novel selective pressure from the discharge of heavy metals could have significant impact on the environmental selection of antibiotic resistance genes (Alonso et al. 2001). In this study, comparison of the fingerprinting profiles derived from the MDR $V$. cholerae isolates revealed a close relatedness between the MDR and heavy metal resistance phenotypes, suggesting that heavy metal pollution most likely selects for antibiotic resistance and vice versa (Baker-Austin et al. 2006). The DNA transfer between antimicrobial-resistant bacteria from fish hatcheries and other pathogenic bacteria has been reported (Rhodes et al. 2000), which imposes potential threat upon human health. Thus, in the future studies, continuous monitoring of genetic evolution of $V$. cholerae in fish considered as natural reservoirs and vectors of resistance (Laviad-Shitrit et al. 2018) and identification of risk factors are crucial for assuring food safety and human health.

\section{Conclusions}

In this study, for the first time, we isolated and characterized $V$. cholerae from A. nobilis and P. pekinensis, and determined heavy metal tolerance profiles of $400 \mathrm{~V}$. cholerae isolates recovered from four commonly consumed freshwater fish $(A$. nobilis, $C$. auratus, $C$. idellus, and $P$. pekinensis) collected in July and August of 2017 in Shanghai, China. Also, our data revealed an extremely low occurrence of pathogenic $V$. cholerae carrying the major virulence genes $\operatorname{ct} x A B$ $(0.0 \%)$, tcpA $(0.0 \%)$, ace $(0.0 \%)$, and zot $(0.0 \%)$, as well as potential toxin genes $m s h A(0.8 \%)$ and pilA $(0.8 \%)$. However, high incidence of virulence-associated genes was observed, including the RTX toxin gene cluster ( $r t x A-D)(83.0-$ $97.0 \%)$, hlyA (87.8\%), th (76.0\%), and hapA (95.0\%). Meanwhile, high percentages of resistance to antimicrobial agents STR (65.3\%), AMP (44.5\%), and RIF (24.0\%) were also observed. Approximately $30.5 \%$ (122/400) of the isolates displayed MDR phenotypes with 42 different resistance patterns (MARI > 0.20), which were significantly different among the four fish species (MARI, $P=0.001$ ). Additionally, tolerance of isolates to heavy metals $\mathrm{Hg}^{2+}$ (49.3\%), $\mathrm{Zn}^{2+}(30.3 \%)$, and $\mathrm{Pb}^{2+}(12.0 \%)$ was observed. Approximately $73.8 \%(90 / 122)$ of the MDR isolates were also tolerant to heavy metals evaluated. C. auratus was likely exposed to antimicrobial drugs and heavy metals mostly when compared with the other fish species. The ERIC-PCR-based fingerprinting of the $400 \mathrm{~V}$. cholerae isolates revealed 328 ERIC-genotypes, and the MDR isolates were classified into 106 ERIC-genotypes, which demonstrated a large degree of genomic variation among the isolates. Overall, the results in this study revealed divergent virulence, resistance phenotypes, and ERIC-genotypes of the $V$. cholerae isolates recovered from the four fish species. The increasing resistance of $V$. cholerae imposed potential threat upon human health. Therefore, governments particularly in developing nations, aquaculture industry, and food consumers should work together toward eliminating and controlling the leading waterborne pathogen worldwide. In the future research, molecular mechanisms underlying the co-selection for antimicrobial and heavy metal resistant $V$. cholerae will be investigated.

Funding information This research was supported by the grants from the Shanghai Municipal Science and Technology Commission (grant number 17050502200) and National Natural Science Foundation of China (grant number 31671946).

Open Access This article is distributed under the terms of the Creative Commons Attribution 4.0 International License (http:// creativecommons.org/licenses/by/4.0/), which permits unrestricted use, distribution, and reproduction in any medium, provided you give appropriate credit to the original author(s) and the source, provide a link to the Creative Commons license, and indicate if changes were made.

\section{References}

Acosta CJ, Galindo CM, Kimario J, Senkoro K, Urassa H, Casals C, Corachan M, Eseko N, Tanner M, Mshinda H, Lwilla F, Vila J, Alonso PL (2001) Cholera outbreak in southern Tanzania: risk factors and patterns of transmission. Emerg Infect Dis 7:583-587 
Ahmed HA, El Bayomi RM, Hussein MA, Khedr MHE, Abo Remela EM, El-Ashram AMM (2018) Molecular characterization, antibiotic resistance pattern and biofilm formation of Vibrio parahaemolyticus and $V$. cholerae isolated from crustaceans and humans. Int J Food Microbiol 274:31-37

Akoachere JF, Mbuntcha CK (2014) Water sources as reservoirs of Vibrio cholerae $\mathrm{O} 1$ and non-O1 strains in Bepanda, Douala (Cameroon): relationship between isolation and physico-chemical factors. BMC Infect Dis 14:421

Ali M, Nelson AR, Lopez AL, Sack DA (2015) Updated global burden of cholera in endemic countries. PLoS Negl Trop Dis 9:e0003832

Alonso A, Sanchez P, Martinez JL (2001) Environmental selection of antibiotic resistance genes. Environ Microbiol 3:1-9

Austin B (2010) Vibrios as causal agents of zoonoses. Vet Microbiol 140: 310-317

Baker-Austin C, Oliver JD, Alam M, Ali A, Waldor MK, Qadri F, Martinez-Urtaza J (2018) Vibrio spp. infections. Nat Rev Dis Primers 4(8)

Baker-Austin C, Wright MS, Stepanauskas R, McArthur JV (2006) Coselection of antibiotic and metal resistance. Trends Microbiol 14: 176-182

Bakhshi B, Barzelighi HM, Adabi M, Lari AR, Pourshafie MR (2009) A molecular survey on virulence associated genotypes of non-O1 nonO139 Vibrio cholerae in aquatic environment of Tehran, Iran. Water Res 43:1441-1447

Baron S, Larvor E, Chevalier S, Jouy E, Kempf I, Granier SA, Lesne J (2017) Antimicrobial susceptibility among urban wastewater and wild shellfish isolates of non-O1/non-O139 Vibrio cholerae from La Rance Estuary (Brittany, France). Front Microbiol 8:1637

Benitez JA, Silva AJ (2016) Vibrio cholerae hemagglutinin(HA)/protease: an extracellular metalloprotease with multiple pathogenic activities. Toxicon 115:55-62

Bhuyan SK, Vairale MG, Arya N, Yadav P, Veer V, Singh L, Yadava PK, Kumar P (2016) Molecular epidemiology of Vibrio cholerae associated with flood in Brahamputra River valley, Assam, India. Infect Genet Evol 40:352-356

Boustanshenas M, Bakhshi B, Ghorbani M, Norouzian D (2013) Comparison of two recombinant systems for expression of cholera toxin B subunit from Vibrio cholerae. Indian J Med Microbiol 31: $10-14$

Briquaire R, Colwell RR, Boncy J, Rossignol E, Dardy A, Pandini I, Villeval F, Machuron JL, Huq A, Rashed S, Vandevelde T, Rozand C (2017) Application of a paper based device containing a new culture medium to detect Vibrio cholerae in water samples collected in Haiti. J Microbiol Methods 133:23-31

Ceccarelli D, Chen A, Hasan NA, Rashed SM, Huq A, Colwell RR (2015) Non-O1/non-O139 Vibrio cholerae carrying multiple virulence factors and V. cholerae $\mathrm{O} 1$ in the Chesapeake Bay, Maryland. Appl Environ Microbiol 81:1909-1918

Chiavelli DA, Marsh JW, Taylor RK (2001) The mannose-sensitive hemagglutinin of Vibrio cholerae promotes adherence to zooplankton. Appl Environ Microbiol 67:3220-3225

Choopun N, Louis V, Huq A, Colwell RR (2002) Simple procedure for rapid identification of Vibrio cholerae from the aquatic environment. Appl Environ Microbiol 68:995-998

Colombo MM, Mastrandrea S, Leite F, Santona A, Uzzau S, Rappelli P, Pisano M, Rubino S, Cappuccinelli P (1997) Tracking of clinical and environmental Vibrio cholerae $\mathrm{O} 1$ strains by combined analysis of the presence of toxin cassette, plasmid content and ERIC PCR. FEMS Immunol Med Microbiol 19:33-45

Devlin EW (2006) Acute toxicity, uptake and histopathology of aqueous methyl mercury to fathead minnow embryos. Ecotoxicology 15:97110

Fiore AE, Michalski JM, Russell RG, Sears CL, Kaper JB (1997) Cloning, characterization, and chromosomal mapping of a phospholipase (lecithinase) produced by Vibrio cholerae. Infect Immun 65:3112-3117

Fri J, Ndip RN, Njom HA, Clarke AM (2018) Antibiotic susceptibility of non-cholera Vibrios isolated from farmed and wild marine fish (Argyrosomus japonicus), implications for public health. Microb Drug Resist. https://doi.org/10.1089/mdr.2017.0276

Fullner KJ, Mekalanos JJ (1999) Genetic characterization of a new type IV-A pilus gene cluster found in both classical and El Tor biotypes of Vibrio cholerae. Infect Immun 67:1393-1404

Gao H, Xu J, Lu X, Li J, Lou J, Zhao H, Diao B, Shi Q, Zhang Y, Kan B (2018) Expression of hemolysin is regulated under the collective actions of HapR, Fur, and HlyU in Vibrio cholerae El Tor Serogroup O1. Front Microbiol 9:1310

Ghosh A, Ramamurthy T (2011) Antimicrobials \& cholera: are we stranded? Indian J Med Res 133:225-231

Goel AK, Jiang SC (2011) Association of heavy rainfall on genotypic diversity in $V$. cholerae isolates from an outbreak in India. Int $\mathrm{J}$ Microbiol 2011:230597

Gu W, Yin J, Yang J, Li C, Chen Y, Yin J, Xu W, Zhao S, Liang J, Jing H, Fu X (2014) Characterization of Vibrio cholerae from 1986 to 2012 in Yunnan Province, southwest China bordering Myanmar. Infect Genet Evol 21:1-7

Halder M, Mookerjee S, Batabyal P, Palit A (2017) Environmental Vibrio cholerae non O1/non O139 from the Gangetic delta: a diarrhoeal disease purview. Int J Environ Health Res 27:241-251

Halpern M, Gancz H, Broza M, Kashi Y (2003) Vibrio cholerae hemagglutinin/protease degrades chironomid egg masses. Appl Environ Microbiol 69:4200-4204

Halpern M, Izhaki I (2017) Fish as hosts of Vibrio cholerae. Front Microbiol 8:282

Hasan NA, Ceccarelli D, Grim CJ, Taviani E, Choi J, Sadique A, Alam M, Siddique AK, Sack RB, Huq A, Colwell RR (2013) Distribution of virulence genes in clinical and environmental Vibrio cholerae strains in Bangladesh. Appl Environ Microbiol 79:5782-5785

He X, Nie X, Yang Y, Liu X, Pan D, Cheng Z, Liang X (2012) Multibiomarker responses in fishes from two typical marine aquaculture regions of South China. Mar Pollut Bull 64:2317-2324

He Y, Tang Y, Sun F, Chen L (2015) Detection and characterization of integrative and conjugative elements (ICEs)-positive Vibrio cholerae isolates from aquacultured shrimp and the environment in Shanghai, China. Mar Pollut Bull 101:526-532

$\mathrm{Hu}$ Q, Chen L (2016) Virulence and antibiotic and heavy metal resistance of Vibrio parahaemolyticus isolated from Crustaceans and Shellfish in Shanghai, China. J Food Prot 79:1371-1377

Jia B, Yin H, Duan L, Geng Z, Wang Z, Zheng J, Liu X, Chen J, Du J (2016) China agriculture yearbook. In: Lei L, Yuan H (eds) The agricultural economic statistics. China Agriculture Press, Beijing, pp 272-273 (in Chinese)

Jiang F, Bi R, Deng L, Kang H, Gu B, Ma P (2018) Virulence-associated genes and molecular characteristics of non-O1/non-O139 Vibrio cholerae isolated from hepatitis B cirrhosis patients in China. Int $\mathrm{J}$ Infect Dis 74:117-122

Jing H, Gao L, Zhang M, Wang N, Lin X, Zhang L, Wu S (2016) Establishment from the snout and kidney of goldfish, Carassius auratus, of two new cell lines and their susceptibility to infectious pancreatic necrosis virus. Fish Physiol Biochem 42:303-311

Kitaoka M, Miyata ST, Unterweger D, Pukatzki S (2011) Antibiotic resistance mechanisms of Vibrio cholerae. J Med Microbiol 60:397407

Krumperman PH (1983) Multiple antibiotic resistance indexing of Escherichia coli to identify high-risk sources of fecal contamination of foods. Appl Environ Microbiol 46:165-170

Kumar P, Peter WA, Thomas S (2010) Rapid detection of virulenceassociated genes in environmental strains of Vibrio cholerae by multiplex PCR. Curr Microbiol 60:199-202 
Lalitha P, Siti Suraiya MN, Lim KL, Lee SY, Nur Haslindawaty AR, Chan YY, Ismail A, Zainuddin ZF, Ravichandran M (2008) Analysis of $l o l B$ gene sequence and its use in the development of a PCR assay for the detection of Vibrio cholerae. J Microbiol Methods 75:142-144

Lan CC, Love DR (2012) Molecular characterisation of bacterial community structure along the intestinal tract of Zebrafish (Danio rerio): a pilot study. ISRN Microbiol 2012:590385

Laviad-Shitrit S, Sharaby Y, Izhaki I, Peretz A, Halpern M (2018) Antimicrobial susceptibility of environmental non-O1/non-O139 Vibrio cholerae isolates. Front Microbiol 9:1726

Letchumanan V, Pusparajah P, Tan LT, Yin WF, Lee LH, Chan KG (2015) Occurrence and antibiotic resistance of Vibrio parahaemolyticus from Shellfish in Selangor, Malaysia. Front Microbiol 6:1417

Li T, Li M, Miao Y, Yang Y (2017) Distribution and virulence genes of pathogenic Vibrio in freshwater fish and their living environment in Chengdu in 2016. J Applied Prev Med 23:469-471 in Chinese

Li XQ, Wang M, Deng ZA, Shen JC, Zhang XQ, Liu YF, Cai YS, Wu XW, Di B (2015) Survivability and molecular variation in Vibrio cholerae from epidemic sites in China. Epidemiol Infect 143:288 297

Lin W, Fullner KJ, Clayton R, Sexton JA, Rogers MB, Calia KE, Calderwood SB, Fraser C, Mekalanos JJ (1999) Identification of a vibrio cholerae RTX toxin gene cluster that is tightly linked to the cholera toxin prophage. Proc Natl Acad Sci U S A 96:1071-1076

Ling V, Kartner N, Sudo T, Siminovitch L, Riordan JR (1983) Multidrugresistance phenotype in Chinese hamster ovary cells. Cancer Treat Rep 67:869-874

Lu H, Yuan Y, Sun N, Bi Z, Guan B, Shao K, Wang T, Bi Z (2017) Characterization of Vibrio cholerae isolates from 1976 to 2013 in Shandong Province, China. Braz J Microbiol 48:173-179

Malik A, Aleem A (2011) Incidence of metal and antibiotic resistance in Pseudomonas spp. from the river water, agricultural soil irrigated with wastewater and groundwater. Environ Monit Assess 178:293308

Matyar F (2012) Antibiotic and heavy metal resistance in bacteria isolated from the Eastern Mediterranean Sea coast. Bull Environ Contam Toxicol 89:551-556

McGrath BM, O’Halloran JA, Piterina AV, Pembroke JT (2006) Molecular tools to detect the IncJ elements: a family of integrating, antibiotic resistant mobile genetic elements. J Microbiol Methods 66:32-42

Meacham KJ, Zhang L, Foxman B, Bauer RJ, Marrs CF (2003) Evaluation of genotyping large numbers of Escherichia coli isolates by enterobacterial repetitive intergenic consensus-PCR. J Clin Microbiol 41:5224-5226

Moorthy S, Watnick PI (2004) Genetic evidence that the Vibrio cholerae monolayer is a distinct stage in biofilm development. Mol Microbiol 52:573-587

Ottaviani D, Medici L, Talevi G, Napoleoni M, Serratore P, Zavatta E, Bignami G, Masini L, Chierichetti S, Fisichella S, Leoni F (2018) Molecular characterization and drug susceptibility of non-O1/O139 $V$. cholerae strains of seafood, environmental and clinical origin, Italy. Food Microbiol 72:82-88

Preeprem S, Mittraparp-arthorn P, Bhoopong P, Vuddhakul V (2014) Isolation and characterization of Vibrio cholerae isolates from seafood in Hat Yai City, Songkhla, Thailand. Foodborne Pathog Dis 11: 881-886

Ramirez-Perez T, Sarma SS, Nandini S (2004) Effects of mercury on the life table demography of the rotifer Brachionus calyciflorus Pallas (Rotifera). Ecotoxicology 13:535-544

Ranjbar R, Hosseini MJ, Kaffashian AR, Farshad S (2010) An outbreak of shigellosis due to Shigella flexneri serotype 3a in a prison in Iran. Arch Iran Med 13:413-416

Rhodes G, Huys G, Swings J, McGann P, Hiney M, Smith P, Pickup RW (2000) Distribution of oxytetracycline resistance plasmids between aeromonads in hospital and aquaculture environments: implication of Tn1721 in dissemination of the tetracycline resistance determinant tet A. Appl Environ Microbiol 66:3883-3890

Rivera IG, Chowdhury MA, Huq A, Jacobs D, Martins MT, Colwell RR (1995) Enterobacterial repetitive intergenic consensus sequences and the PCR to generate fingerprints of genomic DNAs from Vibrio cholerae O1, O139, and non-O1 strains. Appl Environ Microbiol 61:2898-2904

Rivera IN, Chun J, Huq A, Sack RB, Colwell RR (2001) Genotypes associated with virulence in environmental isolates of Vibrio cholerae. Appl Environ Microbiol 67:2421-2429

Ruenchit P, Reamtong O, Siripanichgon K, Chaicumpa W, Diraphat P (2017) New facet of non-O1/non-O139 Vibrio cholerae hemolysin A: a competitive factor in the ecological niche. FEMS Microbiol Ecol 93:12

Runft DL, Mitchell KC, Abuaita BH, Allen JP, Bajer S, Ginsburg K, Neely MN, Withey JH (2014) Zebrafish as a natural host model for Vibrio cholerae colonization and transmission. Appl Environ Microbiol 80:1710-1717

Sawasdee B, Kohler HR (2010) Metal sensitivity of the embryonic development of the ramshorn snail Marisa cornuarietis (Prosobranchia). Ecotoxicology 19:1487-1495

Schurmann D, Ebert N, Kampf D, Baumann B, Frei U, Suttorp N (2002) Domestic cholera in Germany associated with fresh fish imported from Nigeria. Eur J Clin Microbiol Infect Dis 21:827-828

Senderovich Y, Izhaki I, Halpern M (2010) Fish as reservoirs and vectors of Vibrio cholerae. PLoS One 5:e8607

Simpson EH (1972) Measurement of diversity. J Cardiothorac Vase Anesth 27:261

Singh DV, Isac SR, Colwell RR (2002) Development of a hexaplex PCR assay for rapid detection of virulence and regulatory genes in Vibrio cholerae and Vibrio mimicus. J Clin Microbiol 40:4321-4324

Song Y, Yu P, Li B, Pan Y, Zhang X, Cong J, Zhao Y, Wang H, Chen L (2013) The mosaic accessory gene structures of the SXT/R391-like integrative and conjugative elements derived from Vibrio spp. isolated from aquatic products and environment in the Yangtze River Estuary, China. BMC Microbiol 13:214

Sulca MA, Orozco R, Alvarado DE (2018) Antimicrobial resistance not related to 1,2,3 integrons and Superintegron in Vibrio spp. isolated from seawater sample of Lima (Peru). Mar Pollut Bull 131:370-377

Sun T, Che H, Qi B, Wang Y, Dong Y, Xia X, Wang H, Gui K, Zheng Y, Zhao H, Ma Q, Du R, Zhang X (2018) Characterization of vertical distribution and radiative forcing of ambient aerosol over the Yangtze River Delta during 2013-2015. Sci Total Environ 650: 1846-1857

Tang Y, Tao P, Tan J, Mu H, Peng L, Yang D, Tong S, Chen L (2014) Identification of bacterial community composition in freshwater aquaculture system farming of Litopenaeus vannamei reveals distinct temperature-driven patterns. Int J Mol Sci 15:13663-13680

Taviani E, Ceccarelli D, Lazaro N, Bani S, Cappuccinelli P, Colwell RR, Colombo MM (2008) Environmental Vibrio spp., isolated in Mozambique, contain a polymorphic group of integrative conjugative elements and class 1 integrons. FEMS Microbiol Ecol 64:45-54

Thapa Shrestha U, Adhikari N, Maharjan R, Banjara MR, Rijal KR, Basnyat SR, Agrawal VP (2015) Multidrug resistant Vibrio cholerae O1 from clinical and environmental samples in Kathmandu city. BMC Infect Dis 15:104

Thornley MJ (1960) The differentiation of Pseudomonas from other gram-negative bacteria on the basis of arginine metabolism. J Appl Bacteriol 23:37-52

Traore O, Martikainen O, Siitonen A, Traore AS, Barro N, Haukka K (2014) Occurrence of Vibrio cholerae in fish and water from a reservoir and a neighboring channel in Ouagadougou, Burkina Faso. J Infect Dev Ctries 8:1334-1338 
Tulatorn S, Preeprem S, Vuddhakul V, Mittraparp-Arthorn P (2018) Comparison of virulence gene profiles and genomic fingerprints of Vibrio cholerae $\mathrm{O} 1$ and non-O1/non-O139 isolates from diarrheal patients in southern Thailand. 46:31

Vezzulli L, Pruzzo C, Huq A, Colwell RR (2010) Environmental reservoirs of Vibrio cholerae and their role in cholera. Environ Microbiol Rep 2:27-33

Waldor MK, Mekalanos JJ (1996) Lysogenic conversion by a filamentous phage encoding cholera toxin. Science 272:1910-1914

Wang R, Lou J, Liu J, Zhang L, Li J, Kan B (2012) Antibiotic resistance of Vibrio cholerae O1 El Tor strains from the seventh pandemic in China, 1961-2010. Int J Antimicrob Agents 40:361-364

Weisburg WG, Barns SM, Pelletier DA, Lane DJ (1991) 16s ribosomal DNA amplification for phylogenetic study. J Bacteriol 173:697-703

Woolhouse M, Farrar J (2014) Policy: an intergovernmental panel on antimicrobial resistance. Nature 509:555-557

Wuana RA, Okieimen FE (2011) Heavy metals in contaminated soils: a review of sources, chemistry, risks and best available strategies for remediation. Isrn Ecology 2011:1-20

Xing M, Hou Z, Yuan J, Liu Y, Qu Y, Liu B (2013) Taxonomic and functional metagenomic profiling of gastrointestinal tract microbiome of the farmed adult turbot (Scophthalmus maximus). FEMS Microbiol Ecol 86:432-443

Yilmaz S, Sova M (2018) Antimicrobial activity of trans-cinnamic acid and commonly used antibiotics against important fish pathogens and nonpathogenic isolates. J Appl Microbiol. https://doi.org/10.1111/ jam. 14097

You Y, Fu C, Zeng X, Fang D, Yan X, Sun B, Xiao D, Zhang J (2008) A novel DNA microarray for rapid diagnosis of enteropathogenic bacteria in stool specimens of patients with diarrhea. J Microbiol Methods 75:566-571

Yu L, Zhou Y, Wang R, Lou J, Zhang L, Li J, Bi Z, Kan B (2012) Multiple antibiotic resistance of Vibrio cholerae serogroup O139 in China from 1993 to 2009. PLoS One 7:e38633

Zago V, Zambon M, Civettini M, Zaltum O, Manfrin A (2017) Virulenceassociated factors in Vibrio cholerae non-O1/non-O139 and $V$. mimicus strains isolated in ornamental fish species. J Fish Dis 40:1857-1868

Zhang J, Zhu L, Li F (2018) Comparison of toxic metal distribution characteristics and health risk between cultured and wild fish captured from Honghu City, China. Int J Environ Res Public Health. https://doi.org/10.3390/ijerph15020334

Publisher's note Springer Nature remains neutral with regard to jurisdictional claims in published maps and institutional affiliations. 